\title{
Braddock syndrome
}

INSERM

\section{Source}

INSERM. (1999). Orphanet: an online rare disease and orphan drug data base. Braddock syndrome. ORPHA:52047

Braddock syndrome is a rare malformation syndrome with multiple congenital abnormalities, described in 2 siblings, that is characterized by VACT ERL -like association in combination with pulmonary hypertension, laryngeal webs, blue sclerae, abnormal ears, persistent growth deficiency and normal intellect. 